\title{
Percepções do Público Infantil sobre uma Peça de Teatro de Temática Científica
}

\section{Children's Perceptions of a Science Theatre}

\author{
Leonardo Maciel Moreira ${ }^{\text {(1) }}$ Brasil \\ Viktória Aparecida Gomes Silva Coelho \\ Brasil \\ Laise Novellino Nunes de Souza \\ Brasil
}

O teatro de temática científica é uma prática na educação em ciências que visa a alfabetização científica. O objetivo desta pesquisa foi explicitar e analisar o impacto de uma peça de teatro de temática científica sobre o público infantil. Para isso desenvolveu-se uma investigação qualitativa no intuito de elucidar as percepções das crianças a partir dos desenhos produzidos por elas a respeito de um espetáculo teatral de temática científica e da análise de informações obtidas por meio de grupo focal. Os colaboradores foram 131 crianças de uma escola municipal da cidade de Macaé. A partir dos dados encontrados verificou-se que uma peça de teatro de temática científica possui potencial para auxiliar crianças no conhecimento das ciências por mobilizar a atenção e a concentração, por favorecer a retenção de informação e por estimular curiosidade e interesse.

Palavras-chave: Divulgação científica; Teatro de temática científica; Percepção; Infantil.

For science education, a science theatre is a practice aimed to achieve scientific literacy. The purpose of this qualitative study was to reveal and examine the impact of a science theatre on children. For this, we developed a qualitative investigation in a way to elucidate the children's perceptions through drawings that they produced regarding a science theatre show and the analysis of information obtained from a focus group. In all, 131 children from a school at Macaé participated in the study. The findings indicated that science theatre have potential to help children in science learning by stimulating attention and concentration, strengthening information retention and fostering curiosity and interest.

Keywords: Scientific popularization; Science theatre; Perception; Childhood. 


\section{Introdução}

A proposta de alfabetização científica envolve o conhecimento dos principais conceitos da ciência e da tecnologia e de seus processos e impactos na vida cotidiana, bem como da aplicação dos conceitos científicos e tecnológicos em situações de tomada de decisão (Cunha, 2017; Yacobian, 2018). A educação em ciências, nessa perspectiva, exige um processo contínuo, ao longo de toda a vida, e que dificilmente se encerra no universo da escola. Entretanto, isso não reduz o papel fundamental da escola, somente evidencia a necessidade de se fornecer meios para o aprofundamento no conhecimento científico, pois não se pode entender o desenvolvimento sem que o cidadão tenha variadas possibilidades e/ou oportunidades de atualizar seus conhecimentos, sua cultura.

A divulgação científica tem sido um importante caminho para difusão e problematização dos conhecimentos científicos e tecnológicos entre o público não escolar e escolar. Pesquisadores em divulgação científica e em educação não formal têm reconhecido a articulação entre arte e ciência como evolução das formas de se divulgar a ciência (Lopes, 2005; Massarani, \& Almeida, 2006). Essa articulação traz consigo a abordagem do aspecto emocional e estético. No que se refere à divulgação científica especificamente para o público infantil e infanto-juvenil o teatro de temática científica (Moreira, \& Marandino, 2015) se mostra como um caminho potente, devido ao seu caráter interativo, sensorial e lúdico, uma vez que na divulgação de temas da ciência para esse público é importante adotar uma postura instigante, considerando a criança como um ser inteligente e capaz de entender questões complexas (Marques, \& Marandino, 2017; Neves, \& Massarani, 2008).

Nesse contexto, o objetivo desta pesquisa é explicitar e analisar o impacto de uma peça de teatro de temática científica sobre o público infantil. Para isso, adotamos a questão de investigação: o que as crianças percebem de uma peça de teatro de temática científica? Os dados aqui encontrados, bem como a discussão de nossos resultados, podem auxiliar no aprofundamento do conhecimento sobre os aspectos que podem influenciar na aquisição de informação sobre ciência e sobre tecnologia por crianças espectadoras de uma peça de teatro. Isto tem implicações importantes para futuras ações de divulgação científica e de educação não formal visando o público infantil, bem como para a pesquisa nesse campo.

Inicialmente apresentamos uma discussão sobre relações entre o teatro de temática científica, a divulgação científica e a criança, com a finalidade de ressaltar possibilidades de interações proveitosas, e abordamos pesquisas sobre o impacto de peças de teatro de temática científica. Depois descrevemos brevemente o processo de criação da peça Quem roubou meu arco-íris? para que o leitor possa ter um parâmetro do que foi apresentado às crianças. Em seguida descrevemos nosso caminho metodológico, explicitando os autores que balizaram nossas escolhas investigativas e que constituíram a lente tanto para nossas decisões metodológicas quanto para a análise realizada. Por fim, mostramos os dados encontrados, sua discussão e inferimos possibilidades para o desenvolvimento de ações de divulgação científica e de pesquisas futuras. 


\section{O teatro de temática científica e o público infantil}

O teatro de temática científica (TTC) é um meio de se explicitar as relações das ciências da natureza e exatas com seu contexto social, histórico, cultural e apresentar assuntos complexos ou controversos de forma inteligível e multifacetada, sendo desenvolvido em espaços de educação formal e de educação não formal (Saraiva, 2007; Moreira, \& Marandino, 2015). Apesar dos esforços em tipificá-lo (Barbacci, 2002; Chemi, \& Kasstberg, 2015), sua diversidade varia desde espetáculos focalizando conceitos específicos dessas ciências até abordagens artísticas com inspiração em temas científicos e em seus conflitos. A proficuidade da relação entre teatro e ciência reside na possibilidade de se conhecer a ciência para além dos seus conceitos ou experimentos, focalizando uma abordagem mais humanista, na qual "[...] os cientistas poderiam ser desnudados em seres humanos, com suas emoções e conflitos, e os experimentos poderiam ser contextualizados, conhecendo-se os interferentes sociais que influenciaram nas grandes descobertas científicas. (Moreira, \& Marandino, 2015, p. 514).

As relações entre a arte e a educação despertam diversos questionamentos, por exemplo, Zanetti (2018) realiza uma revisão bibliográfica buscando explicitar processos de pedagogização da arte. Esses processos são motivados por intenções como reverter o fracasso escolar, proporcionar a criatividade, ressignificação do mundo, criar uma maneira ampla de abordar o fenômeno educacional, ampliar discussões sobre a experiência estética, proporcionar uma aprendizagem prazerosa, dentre outros. Discutese sobre o risco de a arte tornar-se ilustração de problemas de outros campos e ficar restrita ao aspecto didático. Contrapondo-se a essa perspectiva encontra-se Bião (2009), para o qual a arte é reveladora e constitutiva da vida e do ser humano, construindo realidades e sentidos que extrapolam as proposições de outros campos (educação, ciência, política etc.). Assim o que é caracteristicamente artístico persiste e uma possível subjugação pedagógica (ou didática) da arte configura-se como ilusão. Um exemplo de diálogo promissor entre a arte e a educação ambiental é apresentado por Silveira (2009) ao propor uma educação estética ambiental, a qual visa o reencontro do humano com as dimensões sensível, afetiva e poética.

A presença do TTC na educação em ciências tem sido decorrente de perspectivas educacionais fundamentadas na alfabetização científica e na educação CTS (Acevedo Díaz, Vázquez, \& Manassero, 2003). Algumas propostas têm procurado estabelecer vínculos mais estreitos entre a perspectiva CTS e as Artes, propondo a construção teórica denominada de CTS-Arte (Oliveira, \& Queiroz, 2013; Andrade et al., 2014). O TTC vem sendo considerado um caminho possível para se problematizar a ciência, o cientista e o fazer científico, abrangendo discussões que - para além dos conteúdos conceituais de ciência e de tecnologia - contemplam seus produtos e suas interações com a cultura.

$\mathrm{Na}$ educação não formal e divulgação científica há o reconhecimento de que o TTC pode trazer contribuições para se comunicar sobre ciência e tecnologia. Gardair e Schall (2009) ressaltam que o teatro, assim como a ciência, fornece um modo de ver o mundo, sendo que ele se preocupa em mobilizar as emoções do espectador. O teatro, ao 
trabalhar a sensibilidade, a percepção, a estética, a intuição e as emoções, pode levar ao público uma maior aproximação dos conteúdos científicos e potencializar a divulgação científica, contribuindo para uma maior aproximação da população ao conhecimento construído na ciência e na tecnologia e propiciar novas perspectivas de ver a ciência, a tecnologia e o seu caráter humano (Moreira, \& Marandino, 2015).

No intuito de expressar e comunicar o teatro congrega cenografia, iluminação, dispositivos cênicos, figurinos, maquiagem e máscaras, performance de atores, sons e silêncio, ritmo, fábula e texto. No que se refere a divulgação científica especificamente para o público infantil esses elementos tornam-se potentes em função das próprias características desse público. As culturas infantis são marcadas por quatro pilares estruturadores (Sarmento, 2005): a interação, a reiteração, a ludicidade e a fantasia. $\mathrm{Na}$ infância a aprendizagem da criança é permeada pela interação com os outros nos diferentes espaços de partilha comum. O tempo da criança é um tempo recursivo, reiterado, continuamente reinvestido de novas possibilidades. Um tempo capaz de ser sempre reiniciado e repetido. O lúdico e o brincar têm um espaço importante. A ludicidade é condição de aprendizagem para as crianças em suas diversas fases da construção das suas relações sociais. Por fim, o universo infantil é permeado pela fantasia, pela imaginação, são momentos em que se experimentam outras possibilidades de existência.

Corsaro $(2002 ; 2011)$ explica que a atuação social da criança é mais interativa do que passiva, havendo uma reprodução interpretativa da cultura em que estão imersas. As crianças se apropriam de informações do mundo adulto de forma a atender aos seus interesses, em um processo criativo. Elas não internalizam as normas sociais e culturais, simplesmente, mas atuam ativamente para sua produção e sua transformação. No contato com os diversos atores sociais a criança desenvolve a cultura de pares, entendida como conjunto de atividades, artefatos, valores e preocupações que elas produzem e partilham na interação com os seus pares. Assim, além de negociar, compartilhar e criar cultura com os adultos a com as outras crianças, a criança atende às curiosidades e demandas de seu grupo de pares. A criança é um sujeito social de plenos direitos (Sarmento, \& Pinto, 1997; Sirota, 2001; Sarmento, 2005), isto é, um ator social dotado de capacidade de ação e culturalmente criativo, perspectiva que se contrapõe a visões adultocêntricas (Quinteiro, 2002).

O interesse por elucidar o impacto de peças de teatro de temática científica sobre o público tem sido compartilhado por diversos pesquisadores. Dentre eles, Baum e Huges (2001) analisam o impacto de diferentes espetáculos apresentados ao longo de 10 anos no Museu de Ciências de Boston; Gadair e Schall (2009) investigam a peça "Lição de Botânica", desenvolvida no Museu da Vida (Fundação Oswaldo Cruz/RJ) no ano de 2007; Silveira, Ataíde e Freire (2009) relatam uma experiência com as peças "A trupe da magia" e "O ciclo da água" apresentadas na Semana Nacional de Ciência e Tecnologia nos anos de 2004 e 2005, respectivamente; Kerby et al. (2010) elucidam o impacto do show "The Amanzing Chemistry Circus", apresentado para crianças 
da educação básica nos E. U. A.; Musacchio, Lanza e D’Addezio (2015) descrevem o impacto de um espetáculo sobre o interior do planeta Terra e os terremotos direcionado a crianças da escola secundária na Itália; e Peleg e Baram-Tsabari (2017) investigam o potencial educacional do espetáculo "Robôs e eu" para o público entre 5 e 9 anos visitantes de um museu em Israel. Essas pesquisas foram desenvolvidas por meio de metodologias qualitativas e/ou quantitativas, utilizando-se de observações, entrevistas, questionários, desenhos, pesquisa de opinião e cartões de comentários para coleta dos dados. Os resultados encontrados pelos diferentes investigadores sinalizam que o teatro foi uma experiência positiva para os visitantes.

A pesquisa em tela possui interesses semelhantes às supracitadas, em especial no que se refere a conhecer o que as crianças percebem de uma peça de teatro de temática científica. Entretanto, diferencia-se por procurar explicitar como e porque os elementos do espetáculo mobilizaram a atenção da plateia. Os resultados encontrados e as reflexões aqui construídas podem contribuir para um melhor conhecimento dos fatores interferentes para o sucesso do TTC direcionado ao público infantil.

\section{A construção de um espetáculo infantil sobre Ciências}

O teatro infantil pode ser definido como "produções teatrais realizadas por produtores adultos, destinadas ao público infantil composto por crianças de colo até mais ou menos 12 ou 13 anos de idade" (Ferreira, 2005, p. 51). No Brasil, essa modalidade de teatro surge em meados do século XX, sendo inicialmente desenvolvida por grupos amadores e domésticos e depois por grupos profissionais (Pupo, 1991; Viana, 2019). Importantes grupos podem ser citados, tais como o Tablado de Maria Clara Machado, o Tesp de Júlio Gouveia e Tatiana Belinky e o Tipie de Olga Reverbel (Pupo, 2000). Ferreira (2005) descreve essa prática, destacando que algumas das produções são direcionadas exclusivamente aos projetos teatro-escola. Peças que não entram em cartaz em salas de espetáculo, visando os auditórios e os pátios das escolas. Em muitos casos possuem apelo comercial, cedendo espaço a temáticas, personagens ou autores de cinema ou televisão. Procuram aglutinar prazer, ludicidade, brincadeira, descontração, momentos extra cotidianos e festivos, para isso utilizando-se de piadas, jargões ou gags cômicos, coreografias e músicas folclóricas e tradicionais, dentre outros elementos. A dramaturgia comumente adotada envolve a transposição cênica de contos de fadas ou contos folclóricos, a adaptação de obras literárias infantis, a utilização de textos dramáticos para o teatro infantil já consagrados ou a produção de textos inéditos (autores locais ou criações coletivas). Em geral, os espetáculos utilizam bonecos ou outras formas animadas, muita cor, cenários e figurinos estilizados e universos fictícios e oníricos, visando chamar a atenção através da percepção visual.

Há vínculos do teatro infantil a educação (Ferreira, 2005). De um lado educar para vivência do teatro (ensinar a ser espectador), de outro o teatro coloca-se a serviço da educação escolar através da possibilidade de se veicular componentes do currículo escolar em cena. Em muitas instituições de ensino o teatro infantil é entendido mais 
como produto cultural que pode fortalecer a veiculação de conteúdos curriculares do que um fenômeno visando a apreciação estética e a formação de plateia. Se por um lado essa constatação provoca discussões quanto a real vivência do fenômeno teatral nessas práticas, por outro explicita a conformação de um nicho de trabalho para os profissionais de artes cênicas. Entretanto, é necessário estar atento e evitar o didatismo autoritário (Pupo, 1991; 2000), que suplanta a adoção de conteúdos e temáticas e faz-se perceber nas enfadonhas e verborrágicas explicações à plateia (significados de palavras, pontos de vista, lições de moral etc.), interrompendo a fluência da ação dramática em favor da exposição de uma enxurrada de conhecimentos.

O processo de construção de um espetáculo teatral infantil exige o reconhecimento de que este artefato cultural é criado e pensado por adultos. Assim, a visão adultocêntrica de mundo tende a ser a norma nessas práticas, naturalizando representações e determinando temas. Ferreira (2005) alerta para que as representações e os estereótipos infantis comuns na cena teatral decorrem dessa lógica. Contudo, pondera que cada vez mais há esforço por parte dos produtores com respeito a conscientização sobre esse fenômeno e a contestação de representações estereotipadas da criança e das culturas infantis. O desafio é o de se descobrir uma linguagem própria da infância, adequada para alcançar os pequenos espectadores, tendo em vista as limitações decorrentes da tradução adulta da cultura infantil. Nos últimos anos os palcos têm abordado diversas possibilidades identitárias infantis, conquanto ainda seja frequente nos espetáculos a abordagem de um universo onírico e lúdico, em detrimento de propostas realistas e/ou naturalistas.

A peça teatral Quem roubou meu arco-íris? foi criada em meio ao universo de apontamentos trazidos por Ferreira (2005) e Pupo (1991; 2000). Uma peça criada por adultos visando o público infantil, que teve como desafio suplantar a representações estereotipadas da criança e das culturas infantis. Um tema científico, do universo do adulto, em modificação para o que se acreditava dialogar com as culturas infantis. Os desafios foram grandes e marcados pela vigília constante quanto ao olhar excessivamente adultocêntrico e pelo reconhecimento da diversidade identitária das crianças enquanto material para as cenas. O espetáculo foi uma produção do Projeto Ciênica, que articula extensão universitária, pesquisa acadêmica e ensino de graduação e de pós-graduação, no intuito de investigar e difundir as relações entre a educação em ciências e o teatro.

O processo de criação e de montagem do espetáculo envolveu pesquisas artísticas e estudos científicos. Os integrantes eram estudantes dos cursos de licenciatura em Química, Bacharelado em Química, Engenharia Civil e Enfermagem. O processo teve início com o seguinte questionamento feito aos graduandos: Como a luz se relaciona com sua área de formação? A partir das respostas e de um processo de chuva de ideias foi se desencadeando uma série de propostas, conceitos e metáforas que poderiam aparecer no espetáculo. Alguns deles foram: fotoquímica, quimiluminescência, a luz como um chamado, dar à luz, sabedoria, caminho a percorrer, energia elétrica, transições eletrônicas, cores e fotografia. Ao final dessa etapa, foi criado um roteiro provisório. 
A etapa seguinte envolveu a criação dos personagens que fariam parte do espetáculo. Um critério adotado foi que deveria haver poucos atores no elenco, de maneira a facilitar o transporte e o atendimento às apresentações nas escolas. Assim, delimitamos a peça a três atores que interpretariam todos os personagens necessários. Depois disso, teve início uma pesquisa por personagens de histórias infantis cujo as características poderiam ser utilizadas nos personagens de nossa peça. Acordou-se que um personagem deveria ser questionador, este seria o âncora das cenas. Um segundo seria uma criança. Os outros personagens seriam criados para serem interpretados por um único ator (que mudaria o figurino, a voz e a movimentação corporal para fazer a diferenciação). Também foi decidido que a trama da peça envolveria o sumiço do arcoíris. No desvelamento desse mistério é que seriam discutidos conhecimentos, conceitos e informações sobre a luz.

O passo seguinte foi a elaboração e reelaboração coletiva e contínua do roteiro da peça por meio de improvisações teatrais para experimentar as cenas e os personagens. Nesse ínterim houve a delimitação e o estudo dos conceitos e conhecimentos que seriam discutidos em cada cena. Em alguns casos, para auxiliar na discussão, foram utilizados objetos - dispositivos cênicos. Também durante essa etapa é que os personagens foram definidos: Duda (criança), mãe, Fóton (duende), sol, árvore, lago, luz e chuva. Na Figura 1 são apresentados os conceitos e/ou conhecimentos abordados em cada cena e, quando foi o caso, o dispositivo cênico para ajudar na explicação do conceito. Na Figura 2 apresentamos uma imagem e um trecho do texto da peça para exemplificar como os dispositivos cênicos e os conceitos eram articulados nas cenas.

\begin{tabular}{|c|l|l|}
\hline Cena & Conceitos / Conhecimentos & Objeto \\
\hline 1 & Metáfora, nascimento & - \\
\hline 2 & Fotossíntese, gás carbônico, gás oxigênio, respiração dos seres humanos & Modelo pulmão \\
\hline 3 & Energia solar & - \\
\hline 4 & Reflexão & Espelho \\
\hline 5 & Absorção e emissão de luz, cores & Círculo de Newton \\
\hline 6 & Refração & Jarro com água \\
\hline 7 & Luz e Química & Câmera Polaroid \\
\hline
\end{tabular}

Figura 1. Relação de cenas com dispositivos cênicos

Árvore - Sabe esse ar que você inspirou? Ele possui, dentre vários gases, o gás oxigênio, você não pode ver, não pode tocar, mas ele está aí entrando pelo seu nariz e percorrendo todo o seu corpo. Isso lhe mantém viva!

Fóton - (retira o modelo de pulmão da bolsa). Olha aqui o que acontece quando eu puxo essa borracha para baixo (mostra as bexigas internas se expandindo), tá vendo só? Essa borracha é como se fosse nosso diafragma, esse músculo que tem aqui na boca do estômago (aponta para o próprio corpo), quando a gente contrai o diafragma, é como se a gente puxasse essa borracha, e quando soltamos, é como se o diafragma relaxasse. Quando eu faço esse movimento de puxar a borracha, eu aumento o meu espaço dentro 
da garrafa PET, que é como se fosse essa nossa caixa torácica (aponta para o próprio corpo), quando isso acontece, a pressão interna fica menor que a externa, assim, o ar entra pelas bexigas para corrigir essa diferença de pressão que acabou surgindo.

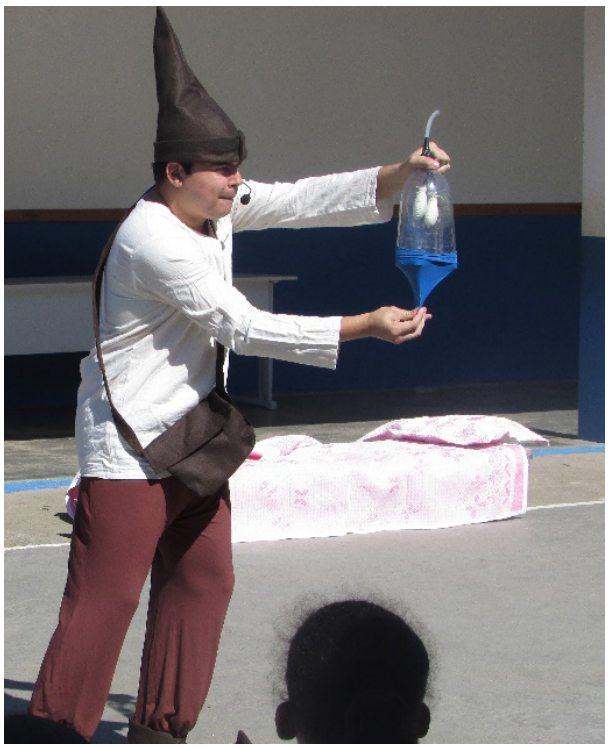

Figura 2. Articulação entre conceitos e/ou conhecimentos e os dispositivos cênicos

Todos os assuntos foram abordados considerando a faixa etária do público alvo, houve um trabalho de transposição (Marandino, 2004) para adequar a maneira com que os conhecimentos seriam apresentados. Os figurinos foram idealizados e confeccionados de maneira que chamasse a atenção da plateia e que possibilitasse sua troca de forma rápida. O cenário foi constituído por poucos elementos, foram eles: cama e travesseiro visando caracterizar o quarto da personagem Duda. As músicas e sons tiveram a função de auxiliar na criação do ambiente imaginário e de fazer a transição de cenas.

$\mathrm{Na}$ história apresentada na peça o duende Fóton perdeu o arco-íris e com isso não consegue encontrar o caminho de sua casa. Duda, uma garota muito esperta, resolve ajudá-lo. Os dois viajam para a floresta das cores. Lá, com a ajuda de vários personagens mágicos elas encontram informações sobre a luz e aos poucos desvendam o que pode ter acontecido para o arco-íris ter sumido. O espetáculo foi construído ao longo de seis meses, tendo também seis meses de temporada no ano de 2017. Ao todo, foram realizadas 24 apresentações do espetáculo, distribuídas por 5 escolas municipais, alcançando cerca de 1200 crianças da educação básica. Nesta investigação são analisados os dados referentes a uma das escolas.

\section{Caminho metodológico}

Esta pesquisa foi desenvolvida na perspectiva da análise qualitativa, tendo contornos de um estudo exploratório (Bogdan, \& Biklen, 1994) e contemplando especificidades da pesquisa com crianças (Delagado, \& Müller, 2005). O intuito foi de explicitar e analisar o que as crianças percebem de uma peça de teatro de temática científica. Os colaboradores foram crianças de uma escola municipal da cidade de 
Macaé, faixa etária de 8 a 11 anos, cursando o segundo, terceiro, quarto ou quinto ano do ensino fundamental. A coleta de dados ocorreu por meio de duas etapas, a realização de desenhos - estratégia que vem sendo adotada em investigações sobre percepção de crianças (Reigada, \& Tozoni-Reis, 2004; Antônio, \& Guimarães, 2005) - e grupo focal (Gomes, 2005), comumente utilizado para elucidar a percepção de um grupo de pessoas sobre conceitos ou identificar problemas. Esta pesquisa foi submetida e aprovada pelo Comitê de Ética em Pesquisa, seu número de Certificado de Apresentação de Apreciação Ética (CAAE) é 63993417.6.0000.5699 e o número do parecer de aprovação é 2.011.572.

O contato do pesquisador com as crianças envolveu um processo de aproximação que englobou diversos momentos, dentre eles, conversas para apresentação da pesquisa, para anúncio e divulgação da peça de teatro, para a realização do espetáculo teatral em si e após o espetáculo, e para a produção do desenho e a realização do grupo focal. Em todos os momentos o pesquisador procurou manter a postura do adulto atípico (Corsaro, 2011), ao longo desse processo ele foi sendo reconhecido como mais um colega.

Inicialmente foi estabelecido contato com a escola e explicado a pesquisa que se pretendia desenvolver. Os termos de consentimento foram distribuídos, assinados e recolhidos. Houve a apresentação da peça de teatro e, devido a questões organizacionais da escola, os desenhos foram realizados uma semana depois da apresentação. Um dos pesquisadores conduziu todo o procedimento de produção do desenho, sendo auxiliado pelas professoras de cada turma. Todo material necessário para a confecção dos desenhos foi fornecido (papel, lápis de cor e canetinhas). Os desenhos foram realizados pelas crianças de cada turma em um único período que, em média, durou cerca de 35 minutos por turma. A frase de comando para o desenho foi: façam um desenho sobre a peça Quem roubou meu arco-íris?, mostrando tudo que vocês lembram sobre a peça de teatro. Nessa etapa o pesquisador utilizou um caderno de campo, no qual registrou as interações durante o processo de confecção dos desenhos.

Ao todo foram produzidos 131 desenhos pelas crianças. Com os desenhos em mãos foi construída uma lista de análise para cada um deles, onde constava todos os elementos da peça identificados em um determinado desenho. $\mathrm{O}$ foco foi a presença do elemento, não sendo relevante a quantidade de vezes que um mesmo elemento apareceu em um determinado desenho. Nesse primeiro nível de análise o interesse foi de verificar a frequência dos elementos. Ao final dessa etapa obtivemos 131 listas. Elas foram comparadas entre si e, utilizando-se de técnicas de categorização temática da análise de conteúdo (Bardin, 2000), foram criadas 18 categorias correspondentes aos elementos da peça desenhados pelas crianças. Três pesquisadores participaram desse procedimento de identificação e categorização, havendo concordância em cerca de $90 \%$ dos casos.

$\mathrm{Na}$ segunda etapa foram selecionadas crianças autoras de 40 dos 131 desenhos para participarem do grupo focal. A seleção de crianças foi decorrente de o grupo focal preconizar um número pequeno de integrantes (de 6 a 10), para que todos tenham oportunidade de se expressar de maneira a possibilitar o aprofundamento no conhecimento das ideias e das concepções (Gomes, 2005) e também para que 
pudéssemos dar voz às crianças e acessar suas interpretações (Corsaro, 2011). Para cada série, foram escolhidas até 10 crianças cujo desenhos apresentaram maior número de elementos. Nesse segundo nível de análise o interesse foi de explicitar o porquê e o como os elementos causaram impacto. Assim os desenhos com maior número de elementos se mostraram mais pertinentes.

O tempo de realização do grupo focal foi variado e dependente da interação entre as crianças, entretanto, na prática o tempo máximo alcançado por um grupo focal foi de trinta minutos. Importante sinalizar que algumas crianças selecionadas faltaram à etapa do grupo focal, com isso a constituição dos grupos focais foi de 7 integrantes para as crianças do $2^{\circ}$ ano, 10 para os do $3^{\circ}$ ano, 9 para os do $4^{\circ}$ ano e 9 para os do $5^{\circ}$ ano. Os grupos focais serão identificados pelo código $\mathrm{Fx}$, onde $\mathrm{x}$ corresponde à série em que as crianças cursavam. Ao todo foram realizadas quatro sessões de grupos focais. Conforme apresentado na Figura 3, as discussões no grupo focal abordaram cinco dimensões:

\begin{tabular}{|l|l|}
\hline Dimensões & Questões orientadoras \\
\hline Impressões sobre a peça & $\begin{array}{l}\text { Sobre o que era a peça de teatro? } \\
\text { Qual história a peça contava? } \\
\text { Quais partes você mais gostou? } \\
\text { Quais partes você menos gostou? } \\
\text { Quais eram os personagens da peça? }\end{array}$ \\
\hline Explicação dos desenhos & Apresente seu desenho para o grupo. \\
\hline Os personagens & $\begin{array}{l}\text { De qual personagem você mais gostou? Por que você gostou desse } \\
\text { personagem? } \\
\text { Você se lembra de alguma coisa legal que esse personagem falou? } \\
\text { Alguém se lembra do que a árvore falou sobre a luz e o arco-íris? } \\
\text { Alguém se lembra do que o sol falou sobre a luz e o arco-íris? } \\
\text { Alguém se lembra do que o lago falou sobre a luz e o arco-íris? } \\
\text { Alguém se lembra do que a luz falou sobre a luz e o arco-íris? } \\
\text { Alguém se lembra do que a chuva falou sobre a luz e o arco-íris? }\end{array}$ \\
\hline Os dispositivos cênicos & $\begin{array}{l}\text { O duende mostrou vários objetos durante a peça, você se lembra de } \\
\text { algum desses objetos? Quais? } \\
\text { Você se lembra do que ele falou sobre esse objeto (mostrar o objeto)? }\end{array}$ \\
\hline O teatro na escola & $\begin{array}{l}\text { Quem gostou de ter teatro na escola? Por quê? } \\
\text { Qual outra história de teatro você gostaria de assistir? }\end{array}$ \\
\hline
\end{tabular}

Figura 3. Questões orientadoras para o grupo focal

No grupo focal procurou-se ao máximo dar liberdade para que cada criança pudesse falar sobre sua produção. Nosso intuito foi o de tornar explícito o que foi representado, uma vez que a interpretação dos desenhos pelos pesquisadores adultos pode não condizer com a intenção das crianças, pois sabe-se que elas possuem culturas próprias (Corsaro, 2011). No grupo focal, guiados pelas questões orientadoras e o objetivo da pesquisa, realizamos leituras da transcrição das falas das crianças, explicitando e localizando informações que remetessem aos interesses de nossa investigação, em um 
processo de codificação e categorização (Bogdan, \& Biklen, 1994). Posteriormente, inferimos a percepção do grupo de crianças a partir do conjunto das falas.

\section{Resultados e discussão}

A produção de desenhos como coleta de dados decorreu dessa atividade ser parte da rotina das crianças colaboradoras desta pesquisa. Durante a realização dos desenhos o pesquisador interagiu com as crianças, contudo não forneceu informações sobre a peça. No lugar de responder diretamente às perguntas voltava os questionamentos às próprias crianças, conforme trechos transcritos do caderno de campo:

E: Tio, qual cor era o arco-íris?

P: Quais cores você lembra?

E: Tinham várias cores. (Transcrição, turma F302)

E: Tio, esqueci as cores do arco-íris.

P: Quais você lembra?

E: Não sei.

P: Então escolhe aquelas que você achar que tinha. (Transcrição, turma F401)

A pouca interação que houve entre as professoras regentes das turmas e as crianças foram relacionadas à gestão da atividade de desenhar. Entretanto, entre as crianças houve troca de informações, por vezes elas mostravam seus desenhos umas para as outras ou conversavam sobre a peça para depois desenhar. Conforme nos relata Corsaro (2009) e Sarmento (2005) essa dinâmica entre as crianças é decorrente da própria cultura infantil, marcada pela interação e pela construção/reconstrução em dialogia com os pares. $\mathrm{O}$ momento do desenho foi um instante em que as crianças explicitaram e dirimiram dúvidas sobre o espetáculo, sendo assistidas pelos seus pares no processo entendimento e de expressão do espetáculo. Os trechos a seguir exemplificam alguns desses momentos:

E1: Tio, qual o nome daquela menina que tinha um chapéu? Que estava procurando o arco-íris? Que tinha um chapéu?

E2: Fóton. (Transcrição, turma F302)

E4: A árvore era o que?

E5: Era uma pessoa. Era a mãe dela.

E4: Era a mãe da menina?

E5: Aham! Ela se troca.

E4: Que doidera. (Transcrição, turma F302)

A atividade de desenho funcionou como um momento de explicitação verbal do que foi percebido sobre a peça e de trocas. Com isso, mais do que representar uma percepção individual sobre o espetáculo, os desenhos das crianças ecoaram a percepção 
coletiva das diferentes turmas.

De acordo com relato das professoras a atividade de desenho faz parte da rotina das crianças. Ao final da realização do desenho a professora regente da turma F302 relatou que aquela turma "não costumava se concentrar em atividades de desenho, geralmente faziam rapidinho", mas que naquele caso estavam envolvidos. Relato semelhante foi feito pela professora da turma F401, segundo a qual a "concentração dos alunos foi boa e fora do normal" pois, em geral, nas atividades de artes os alunos daquela turma "tinham resistência em desenhar ou faziam rapidinho, de qualquer jeito". Elas atribuíram isso ao fato de ter havido uma peça de teatro antes. Esses podem ser indícios de que a peça de teatro teve influência no comportamento das crianças mesmo em um período após a apresentação, fazendo com que o envolvimento com atividades escolares rotineiras fosse melhor do que o habitual. A análise dos desenhos levou a criação das 18 categorias apresentadas na Tabela 1.

Tabela 1. Elementos e sua presença nos desenhos

\begin{tabular}{|c|c|c|}
\hline & Categorias & Total \\
\hline \multirow{8}{*}{ Personagens } & Sol & 105 \\
\hline & Árvore & 98 \\
\hline & Duda & 72 \\
\hline & Duende & 66 \\
\hline & Chuva & 58 \\
\hline & Lago & 42 \\
\hline & Mãe & 27 \\
\hline & Luz & 5 \\
\hline \multirow{4}{*}{ Cenário } & Cama & 43 \\
\hline & Nuvem & 40 \\
\hline & Casa & 20 \\
\hline & Arco-íris & 96 \\
\hline \multirow{3}{*}{$\begin{array}{l}\text { Dispositivos } \\
\text { cênicos }\end{array}$} & Jarro com água & 2 \\
\hline & Círculo de Newton & 2 \\
\hline & Pulmão artificial & 1 \\
\hline \multirow{3}{*}{$\begin{array}{l}\text { Local da } \\
\text { apresentação }\end{array}$} & Ambiente & 6 \\
\hline & Sonoplastia & 3 \\
\hline & Desenho fora de contexto & 46 \\
\hline
\end{tabular}

Na primeira coluna da Tabela 1 estão as categorias criadas a partir da presença de elementos da peça teatral nos desenhos das crianças e a última coluna (total) corresponde ao total de evocações de uma determinada categoria no conjunto de todos os desenhos. Importante destacar a não utilização direta do nome do elemento (e.g. arco-íris), mas sim de uma categoria (e.g. arco-íris) correspondente ao conjunto de um mesmo elemento. Essa sistematização foi utilizada devido ao fato de haver uma diversidade de representações de um mesmo elemento (e.g. arco-íris desenhados com 
sete cores, arco-íris desenhados em preto e branco, arco-íris desenhados apenas com uma cor etc.). Importante destacar que numeramos a categoria pelo desenho de cada criança, ou seja, mesmo que um desenho apresentasse 3 árvores, contabilizamos 1, pois naquele desenho havia o elemento árvore. Quando aparecia nuvem com gotas de chuva, contabilizamos apenas o elemento chuva.

A partir da Tabela 1 verifica-se que a maioria dos personagens do espetáculo estão entre as dez categorias mais evocadas: sol (105), árvore (98), Duda (72), duende (66), chuva (58) e lago (42). Somente os personagens mãe (27) e luz (5) ficaram fora desse grupo. Exemplos de desenhos sobre os personagens são apresentados na Figura 4.

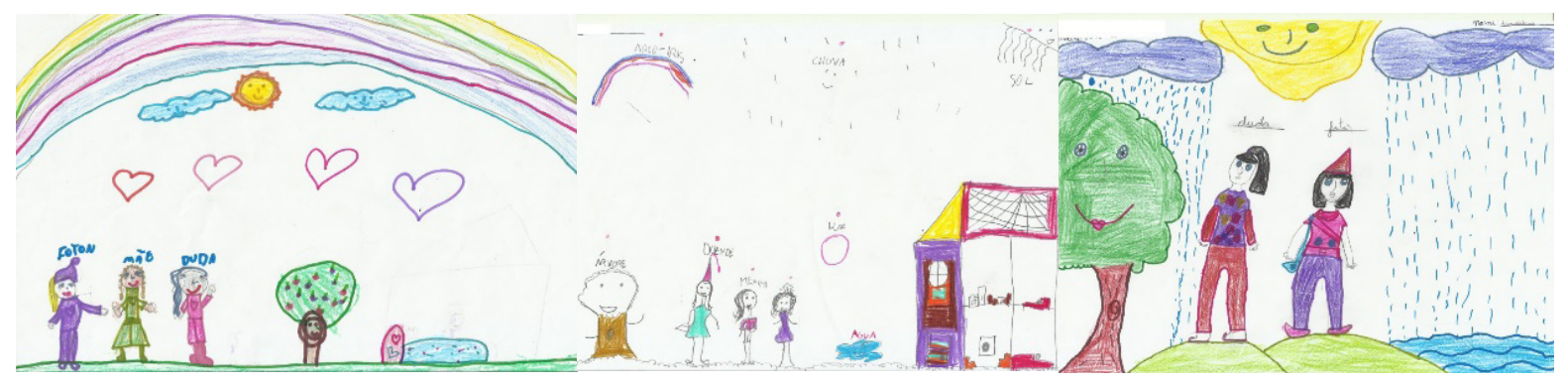

Figura 4. Exemplos de desenhos com personagens

A diferença entre o impacto dos personagens pode ser decorrente de suas características. Os personagens que configuram no grupo dos dez elementos mais presentes possuem características marcantes, tais como figurinos feitos em cores chamativas e, às vezes, com tecidos com brilhos (chuva e lago). Destaca-se que os personagens mais evocados eram marcados por maneiras próprias de se movimentar e de falar, decorrentes do trabalho de corpo e de uso de falsetes, resultantes da pesquisa artística. De outro lado, a personagem mãe possuía características próprias do cotidiano, de pessoas comumente vistas pelas crianças, não possuindo muito apelo. E no caso da luz, o pouco impacto pode ter sido decorrente do fato de ela não aparecer fisicamente em cena: o personagem luz era uma voz em off que conversava com os personagens Duda e duende. Esses resultados são condizentes com a leitura que Sarmento (2005) faz do universo infantil, o qual é marcado pela interação, a reiteração, a ludicidade e a fantasia, uma vez que os personagens mais interativos e fantasiosos é que foram mais percebidos pelo público.

Os dispositivos cênicos utilizados nas cenas foram evocados em cinco desenhos: jarro com água (2), círculo de newton (2) e modelo de pulmão (1). Na Figura 5 é apresentado um desenho com o círculo de Newton e o pulmão artificial. 

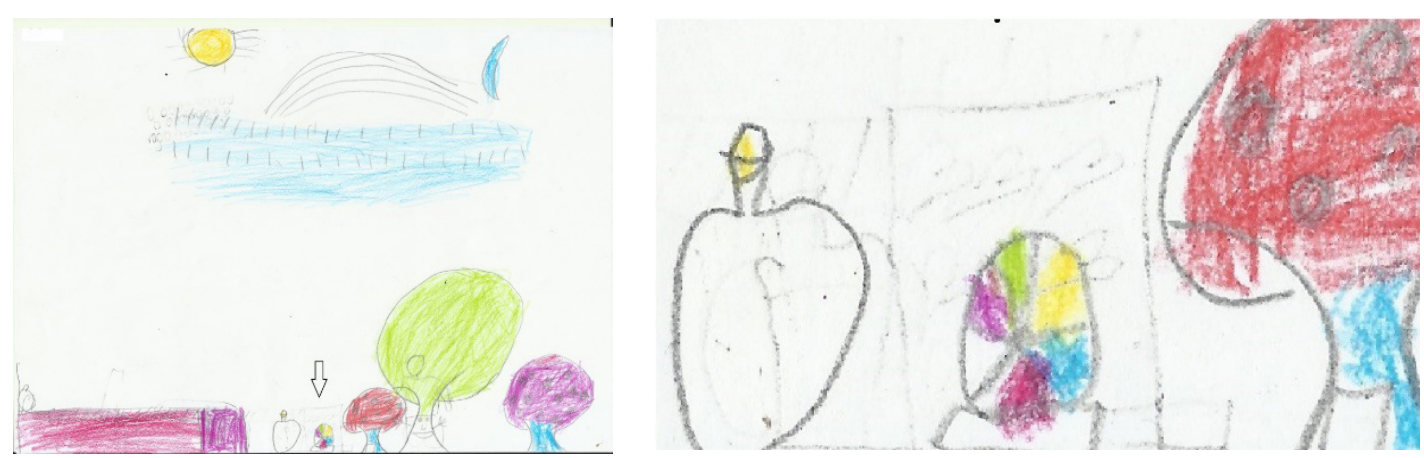

Figura 5. Círculo de Newton e Pulmão artificial (sinalização nossa)

Esse número reduzido de evocações destoa do que foi encontrado por Kerby et al. (2010). Esses autores mostraram que a utilização de demonstrações em suas performances mobilizou a atenção do público. Esses dados decorrentes dos desenhos também destoam do que foi percebido durante as apresentações da peça. Por exemplo, quando o Círculo de Newton girava, ou as bexigas internas do modelo de pulmão enchiam, sorrisos e sons denotando surpresa eram explicitados pela plateia, então, se esperava que o impacto desses dispositivos fosse mais pronunciado. Inferimos que a não presença dos dispositivos nos desenhos pode ser decorrente ou de as crianças terem tido dificuldades em desenhar os dispositivos, ou de o efeito dos dispositivos utilizados ter sido momentâneo, auxiliando em despertar surpresa e deslumbramento, no entanto não tendo seu impacto perpetuado no tempo.

Nos desenhos realizados pelas crianças há indícios de que mesmo um cenário simples exerce impacto, como se percebe pelos desenhos apresentados nas Figuras 6,7 e 8. Foi o que ocorreu com a cama da Duda (único elemento cenográfico do espetáculo), que foi evocado em 43 desenhos. Resultados semelhantes aos nossos foram encontrados por Musacchio, Lanza e D’Addezio (2015), que discutem sobre a simplicidade de se encenar o interior da Terra em um palco de teatro, em comparação com os recursos da televisão ou do cinema, e o trabalho criativo e imaginativo da plateia. Ao que parece, a imaginação e a criatividade das crianças (Sarmento, 2005) compensam cenários minimalistas, decorrentes de poucos recursos para as montagens ou da proposta de encenação, favorecendo a compreensão e o alcance do espetáculo. Alguns desenhos sugerem que a percepção das crianças durante o espetáculo abrangeu não só o que acontece em cena, mas também no entorno [sonoplastia (3) e ambiente (6)] e o próprio momento de vivência de uma peça teatral. 


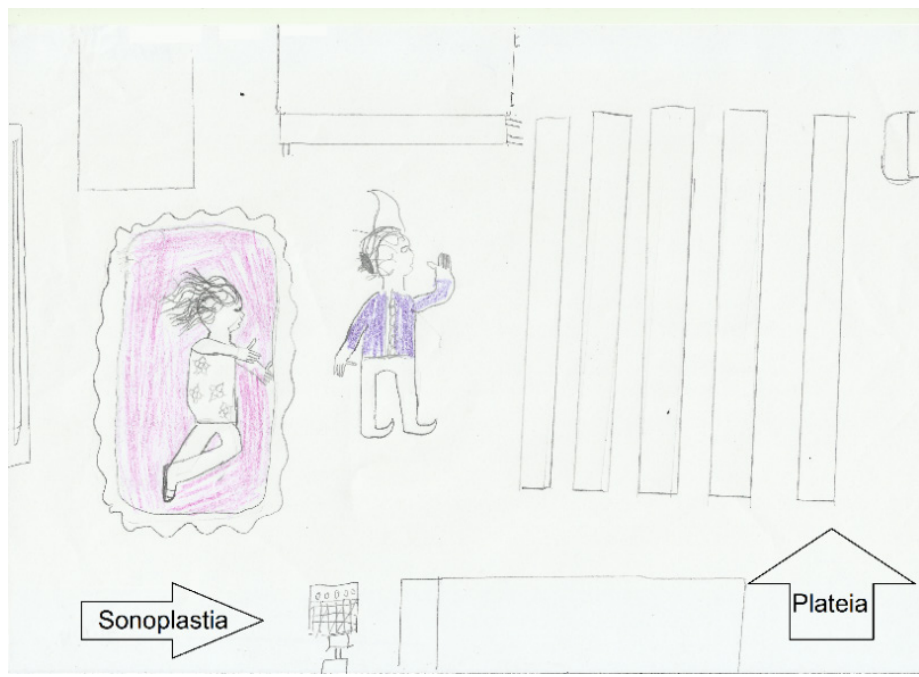

Figura 6. Desenho do ambiente (sinalização nossa)

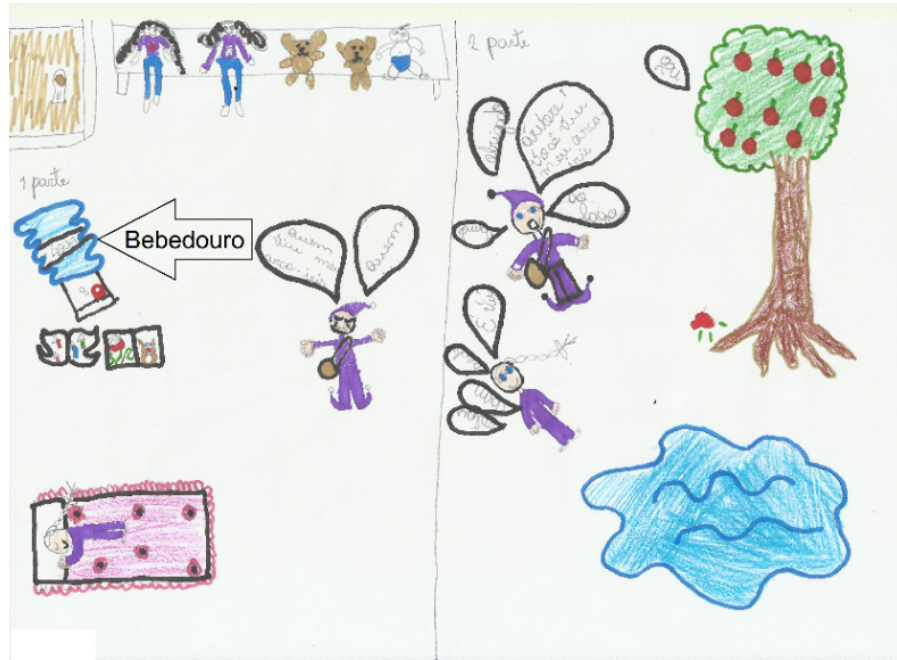

Figura 7. Desenho do ambiente e bebedouro (sinalização nossa)

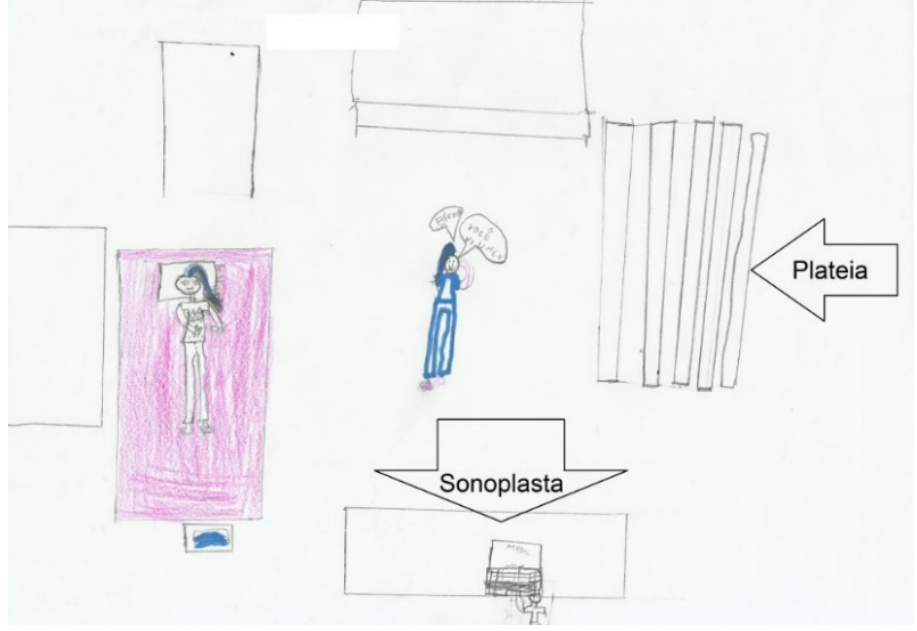

Figura 8. Desenho ambiente e sonoplastia (sinalização nossa)

Alguns elementos desenhados pelas crianças não estiveram presentes no espetáculo em si (Figura 6), foram eles casa (20), nuvem (40) e arco-íris (96). Apesar de não estarem materialmente representados, todos eles poderiam ser inferidos a partir do enredo e dos personagens. 46 desenhos apresentaram elementos que não estavam presentes no espetáculo e não guardavam relação com o mesmo, sendo categorizados como desenho fora de contexto. Esses elementos incluíram pássaros, flores, corações, borboletas, entre outros (Figuras 9 e 10). A partir do que discute Sarmento (2005), esses elementos podem ser resultantes da criatividade das crianças no contato com o que a peça se propôs a contar, bem como do processo de reprodução interpretativa (Corsaro, 2002), já que a atuação social da criança é interativa e que elas se apropriam de informações de forma a atender aos seus interesses. 


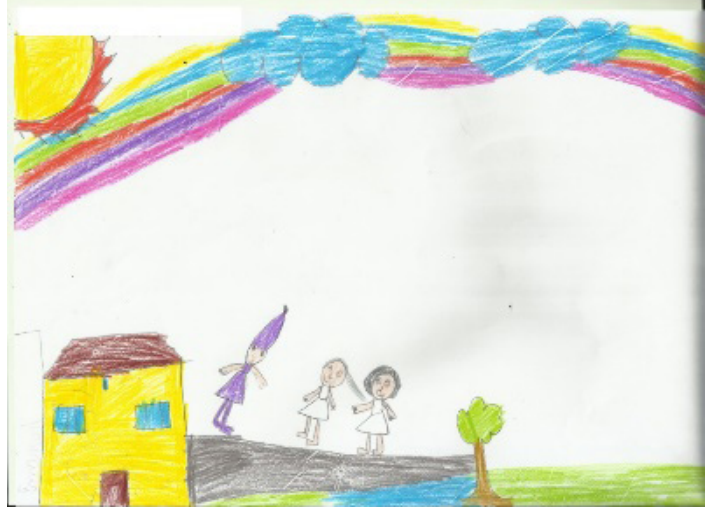

Figura 9. Elementos que não estavam na peça

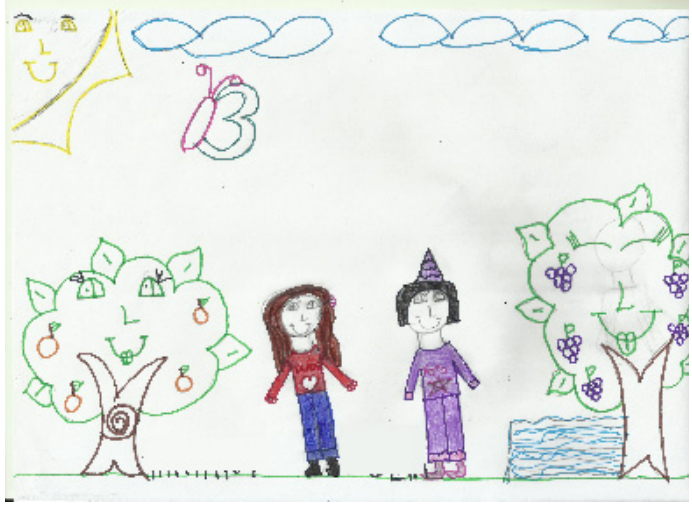

Figura 10. Elemento fora de contexto (borboleta)

Os grupos focais foram momentos em que as vozes das crianças foram mais privilegiadas, pois em agrupamentos menores elas tiveram mais tempo para expor seus pensamentos e ideias. Os dados obtidos nos grupos focais corroboraram que houve compreensão do espetáculo. Crianças de todas as turmas descreveram a história contada, bem como todos os personagens. Também aqui, em acordo com que Sarmento (2005) descreve sobre o universo infantil, os momentos que as crianças mais gostaram foram as cenas em que havia marcações de cena divertidas ou em que estavam presentes os personagens mais animados:

A5: Da parte que ela foi procurar o lago. [...] Porque eu achei engraçado a parte que elas ficaram abaixados e usaram os binóculos.

A1: É... eu achei engraçado quando a fóton começou a brigar com a chuva.

(Grupo focal - F2)

A3: Eu gostei quando... [...] Eu gostei também quando a menina mostrou a foto do arcoíris pra duende.

A1: Eu gostei mais da parte que o duende entra perguntando, "Cadê o arco-íris?".

A8: Eu gostei da parte quando a mãe da Duda acordou a Duda e começou a acordar a Duda e a Duda falou "Para, mãe!". É... Porque ficou muito engraçado e eu gostei muito. (Grupo focal - F4)

Contudo, houve momentos que as crianças sinalizaram não ter gostado:

A1: Eu não gostei da parte... aquela parte do sol. Porque ficou chamando, chamando, chamando...

A6: Eu também não gostei dessa parte

A1: A mãe da menina sempre veste um monte de coisa, aí demora. (Grupo focal - F2)

E: E você?

A9: Da parte da luz

E: Da parte da luz? Por que que você não gostou da parte da luz?

A9: Porque não podia ver ela. (Grupo focal - F5) 
A cena do sol era um momento em que a atriz que interpretava o sol fazia uma troca de figurino. Por vezes essa troca não era realizada de maneira rápida, com isso o tempo para a cena continuar demorava mais do que o esperado, o que tornava a cena longa. Já a personagem luz, que era uma voz em off, não era vista pelas crianças, isso exigia delas um esforço maior para entender a cena. Com respeito ao personagem luz, esses dados corroboram nossa hipótese de que sua baixa presença nos desenhos está relacionada com sua ausência física no palco. Alguns momentos da peça provocaram divergências, sendo indicados por uns como mais gostaram e por outros como menos gostaram:

A2: Eu achei tudo legal, menos a parte da árvore que eu não gostei. Porque ficou muito parada...

A8 : É claro... a árvore não se mexe.

A3: Eu achei legal. Não achei chato. (Grupo focal - F4)

Durante o grupo focal as crianças foram perguntadas sobre os objetos utilizados como dispositivos cênicos. O objeto era apresentado e as perguntas eram feitas. Nesse momento foi perceptível a mesma empolgação verificada na apresentação teatral. Todas as crianças reconheceram o modelo de pulmão utilizado no espetáculo, o associaram à respiração dos seres humanos, e algumas delas estabeleceram relações com o processo de fotossíntese. Entretanto, a descrição do funcionamento do pulmão e dos gases envolvidos no processo de respiração variou entre as turmas:

A5: Quando a gente respira... aí o ar sobe. Aí quando a gente faz assim o ar sai.

A1: Quando a gente tá respirando... aí o coisa... como ele disse, a coisa sobe. Aí a Fóton disse que quando a gente respira aí fica assim e não dá pra respirar.

[...]

E: Então quando ele [fóton] pegou esse objeto ele explicou pra a gente sobre?

A5: Se assoprar...

E: Sobre o quê?

A7: Oxigênio. (Grupo focal - F2)

A8: É tipo o nosso pulmão que tem um negócio assim... aí faz assim e puxa o ar, ai faz assim...

A1: Que a árvore traz oxigênio pra a gente e como a gente respira e expira... e quando a gente traz o ar pra dentro da gente ele limpa. Ele limpa... a gente e quando da gente solta a gente... e quando ele entra ele entra sujo e quando ele sai ele limpa. (Grupo focal - F3)

A2: Da árvore. Que a árvore explicou que sobre o ar, que o ar entrava e como saía, é... Esses pulmões e esse aqui é o nariz, aí toda hora que ela fazia assim, ó, ela respirava.

A1: Eu lembro que ela falou sobre a fotossíntese. Ela falou que quando fazia assim entrava o vento e quando fazia assim o vento saía, o ar. [...] 
A8: É... Que a fotossíntese, é... A fotossíntese é quando as árvores têm a saúde lá... Eles falam que é quando ela tem a respiração, é... só consigo lembrar isso.

A6: Isso é tipo a fotossíntese da árvore. Aí quando a árvore puxava o ar aí saía um ar novo e limpo.

A1: Eu entendi que isso daí era a árvore sugava o ar sujo e e e... soltava o ar limpo. Pra limpar. [...]

E: Vocês lembram qual o gás que a árvore falou que participa dessa respiração?

A1: Gás carbônico. (Vários alunos). É gás carbônico. (Grupo focal - F4)

A6: Ela fala que a gente não tá vendo o arzinho aí tá entrando.

A1: O ar tá entrando e o ar tá saindo. [...]

E: Alguém lembra do gás que tá envolvido na respiração? [...]

A1: Gás carbônico. Eu não sei falar a palavra não, tio

A7: Gás carbônico.

A3: Gás carbônico.

E: Gás carbônico? Só ele?

A1: Ele quem?

E: Gás carbônico, que tinha na respiração?

A4: É, só lembro do gás carbônico

E: Alguém lembra de um tal gás oxigênio?

A3: Ih, esse aí eu não lembro não. (Grupo focal - F5)

As crianças reproduziram parte das explicações sobre respiração fornecidas no espetáculo, inclusive descrevendo o funcionamento do modelo de pulmão e o associando com o pulmão humano. Assim como na produção dos desenhos, também no grupo focal houve grande interação entre as crianças, incluindo complementariedade da fala de uma determinada criança pela fala de outra. Isso traz à tona novamente as características das culturas infantis e exemplifica o movimento do grupo de pares em compartilhar e negociar interpretações de maneira a atender a uma demanda específica (Corsaro, 2002), qual seja, responder as perguntas do grupo focal. Houve evocação de termos científicos (fotossíntese, gás oxigênio e gás carbônico), conquanto não tenham enunciado suas definições científicas. Processo semelhante foi verificado quando se apresentou o Círculo de Newton:

E: Diga pra mim o que você lembra desse objeto.

A 9: Quando liga fica branco.

E: Quando liga fica branco. Por que que fica branco? [...]

A 7: Porque as cores se combinam.

E: As cores se combinam e aí fica branco? É isso mesmo? (Grupo focal - F3)

A1: Que todas as cores do arco-íris, quando se juntam, ela fica branco.

E: Todas as cores do arco-íris, quando você junta, fica branco?

A1: É isso mesmo. 
A3: Quando ela roda ele aí ele fica todo branco depois para, ele volta da cor dele normal. $[\ldots]$

A2: Quando bota no sol, aí aparece, no sol e na chuva, aí aparece.

E: Como é que é? Fala de novo que eu não entendi.

A2: Quando está chovendo e está com sol aparece.

E: Aparece o que?

A5: Sol e chuva. O arco-íris.

A6: O arco-íris

A5: O sol cai e a chuva também, aparece o arco-íris

A6: Quando ela cai do céu ela bate no raio de sol acho, ai faz o arco-íris.

A7: O sol bate na água e a água forma o arco-íris. (Grupo focal - F5)

As crianças explicitaram que as cores do círculo de Newton correspondem às cores do arco íris e que a soma de todas as cores é a cor branca. Esse dado pode ser um indício da ressonância de falas do personagem Duende, que durante o espetáculo repetia essa informação por diversas vezes. Importante destacar que no grupo focal F5 as crianças reproduziram grande parte da explicação apresentada no espetáculo para a formação do arco-íris.

$\mathrm{Na}$ abordagem dos dispositivos cênicos jarro de água e máquina fotográfica houve menos evocação das informações científicas apresentados no espetáculo. Somente crianças dos grupos focais F2 e F4 evocaram informações apresentadas na cena com o jarro de água em que se aborda conhecimentos sobre refração:

E: Que que aconteceu com o pauzinho? Vocês lembram?

A6: Molhou

A2: Parecia que ficou embaçado.

A4: Ficou grande. [...]

E: Vocês lembram que que a Fóton explicou do porquê que ficava grande? Por que que parecia que estava diferente? [...]

A3: O vidro, quando fica com água, o vidro faz ficar mais grosso

A4: Quando o vidro fica com a água faz ficar mais grande, mais grosso.

E: E por que que a água faz isso? A água e o vidro.

A4: Porque a água está dentro de um copo de vidro. [...]

E: Tem a ver com?

A1: Reflexo.

E: Com a luz? Você falou o quê antes? Com o reflexo?

A1: Reflexo.

E: Reflexo? Que que tem a ver o reflexo com isso daqui?

A4: Que o reflexo bate com a água, aí na água o pauzinho vai ficando maior, vai ficando embaçado.

(Grupo focal - F2) 
E: Quem lembra desse objeto que levanta a mão?

A 1: Eu, eu, eu... Porque quando bota água ele se...

A 2: É ilusão.

A 1: Peraí, espera aí... A... O reflexo da água bate no negócio aí fica bagunçado.

E: Fica como?

A 1: Bagunçado.

A4: Tio, quando bota água assim parece que o negócio não tá reto, parece que o negócio tá torto, mas quando tira o negócio tá reto.

$\mathrm{E}$ : Por que que acontece isso?

A4: É... porque tá com o vidro que tá cheio de água.

E: Por que o vidro tá cheio de água? E o que que a água faz pra acontecer isso?

A4: É... Não sei.

A6: É... Quando coloca água aí fica torto, depois, quando tira fica reto aí é ilusão do reflexo da água.

A 2: Eu sei, tio! Por causa do reflexo. O reflexo quanto você tira parece que fica quebrado por causa do reflexo... é... como eu posso explicar? Tipo assim.. Olha, assim, pra uma piscina, aí você vai ver o seu rosto, mas se você mexer vai fica embaraçado.

(Grupo focal - F4)

Na conversa sobre o jarro de água as crianças falaram sobre reflexo, luz, influência da água e influência do vidro, indo em direção à discussão sobre o fenômeno da refração, abordado na cena. Porém, elas não agruparam e elaboraram as informações percebidas para a reprodução da explicação científica do fenômeno apresentada no espetáculo. Entretanto, estabeleceram relações com outros fenômenos semelhantes de suas vidas, por exemplo, o que acontece quando alguém entra na piscina.

No caso da máquina de revelação instantânea, as turmas dos grupos focais F3, F4 e F5 é que evocaram informações a partir do espetáculo:

E: E depois que a imagem foi aparecendo, né? Ela explicou o que que aconteceu pra demorar a imagem aparecer, porque que a imagem sai branca e depois muda, depois aparece. Vocês lembram?

A6: Por causa da claridade. Uma coisa assim.

E: Por causa da claridade?

[...]: Não.

A8: É sim! Você nem lembra.

A7: Vai aparecendo aos muitos.

E: Vai aparecendo aos poucos por causa de que.... de que?

A3: Da luz. (Grupo focal - F3)

E: Que objeto é esse? Que que você lembra dele na peça?

A8: Tio, eu lembro que a mãe dela tirou a foto... Da turma toda aí quando ela tirou ficou tudo embaçado, aí depois não ficou mais embaçado, só ficou um pouco escuro. [...]

A2: Eu lembro que no final, é... Que a moça, ela foi tirar uma foto de todo mundo lá do 
negócio, do refeitório, aí ela explicou que toda a vez que... Era da luz que toda vez que a luz batia ia ficando cada vez mais claro é isso que eu entendi. [...]

E: Vocês disseram que no início, depois que tirou a foto com essa máquina, a foto ficou branca e só depois apareceu a imagem, não é isso? Por que que isso aconteceu? Ela explicou na peça.

A2: Por causa da luz.

Todos: ...por causa da luz...)

E: Por causa da luz?

A2: Por causa da luz pra clarear. Porque quando se sacudia ela...

A6: A mãe da Duda disse que é Química. (Grupo focal - F4)

As crianças rememoraram que para a imagem da foto aparecer depende da luz e que envolve a Química, sem aprofundar nas explicações de como o fenômeno acontece. Isso pode decorrer do fato de que a explicação científica para a revelação instantânea de fotografias é bastante complexa para a faixa etária dos espectadores do espetáculo. Cabe ressaltar que todos os dispositivos cênicos foram reconhecidos pelas crianças, que descreveram as cenas em que eles apareceram, como eles apareceram e reproduziram parte de informações relacionadas a eles. Isso tende a corroborar nossa hipótese de que os dispositivos não apareceram nos desenhos devido a dificuldades em desenhá-los.

Em consonância com o observado por Peleg e Baram-Tsabari (2017), os quais investigaram a aprendizagem no ambiente informal do teatro em museus de ciências, nossos dados demonstram que a experiência teatral vivenciada pelas crianças resultou no reconhecimento do enredo do espetáculo e das motivações e intenções dos personagens, e na explicitação de que as crianças têm dificuldades em assimilar mensagens implícitas no espetáculo. Isto é, a informação científica veiculada pelo espetáculo não é assimilada em suas minúcias. Contudo, podemos nos questionar sobre o quanto essa não assimilação trata-se, de fato, de um fenômeno de não compreensão ou não percepção, ou se decorre da própria interação da criança com o espetáculo. Essa interação não é passiva e a criança seleciona o que é de seu interesse, determinando ativamente o que será compartilhado (Corsaro, 2002). Todavia, a partir das falas das crianças no grupo focal pode-se inferir que o espetáculo forneceu às crianças informações que podem possibilitar um aprofundamento posterior do tema.

As últimas perguntas do grupo focal tiveram a finalidade de elucidar as impressões das crianças sobre o fato de se realizar uma apresentação de teatro de temática científica na escola. Nossos resultados foram similares aos de Kerby et al. (2010), de maneira geral as crianças disseram ter gostado por ser engraçado, ser legal, por aprenderem algumas coisas ("ensinou coisas científicas", grupo focal - F4), por trazer alegria e responsabilidades, por distrair a mente, por não ficar à toa em sala de aula e por ter sido a primeira vez que se assistiu uma peça de teatro. A partir das falas das crianças nesse momento do grupo focal percebe-se que elas reconhecem a característica didática/pedagógica do espetáculo e reconhecem que ele pode ajudar na aquisição de conhecimentos e informações sobre ciências. A partir dos comentários sobre o enredo e 
sobre os personagens durante a realização dos desenhos e do grupo focal, ficou explícito que as crianças apreenderam a peça de teatro em sua totalidade. Além disso, entendem o momento do espetáculo como divertido, descontraído e motivador de aprendizagens. Ao serem questionadas sobre temas para os espetáculos futuros houve um total de 56 falas de indicação, no conjunto dos grupos focais. Os grandes temas indicados e seus percentuais foram corpo humano $(30 \%)$, animais $(23 \%)$, contos infantis $(11 \%)$, dança (5\%), guerreiros (4\%), fazer massinha (4\%) e suspense (4\%).

\section{Conclusões e implicações}

O objetivo desta pesquisa foi explicitar e analisar o impacto de uma peça de teatro de temática científica sobre o público infantil, problematizando como os elementos do espetáculo foram percebidos pelas crianças e favoreceram a aquisição de informações científicas por elas. Para isso foi realizada investigação de cunho qualitativo, baseada na análise de desenhos e de dados coletados por meio de grupo focal. Participaram dessa investigação crianças na faixa etária ente 8 e 11 anos.

Os personagens que mais impactaram as crianças foram aqueles que possuíam figurinos chamativos ou brilhosos ou que eram marcados por maneiras próprias de se movimentar e de falar. Os dispositivos cênicos usados no espetáculo tiveram impacto semelhante a relatos na literatura (Kerby et al., 2010; Voegel, Quashnock, \& Heil, 2004). Dos dados obtidos depreende-se que as crianças foram impactadas pelas características dos personagens e pelos dispositivos cênicos, que guardavam identificação com o universo infantil, marcado pela fantasia e a ludicidade (Sarmento, 2005). Ainda, o comentário de uma professora sugere que a peça teatral induziu a mobilização das crianças para a realização de atividade semelhante às escolares. Entretanto, acreditamos ser necessário o desenvolvimento de outras pesquisas para se elucidar melhor essa relação.

No que se refere à divulgação científica com foco no público infantil (Marques, \& Marandino, 2017; Neves, \& Massarani, 2008), o teatro funcionou como uma estratégia eficiente. Houve apreensão do enredo da peça e das motivações e intenções dos personagens e aquisição de informações que podem ser mobilizadas em posteriores processos de mediação visando a aprendizagem de conceitos científicos. Por exemplo, a partir do modelo de pulmão e da relação entre o gás oxigênio e gás carbônico na fotossíntese, ou da formação da luz branca a partir da soma das cores do arco-íris, problematizada pelo Círculo de Newton. A partir dos resultados encontrados pode-se inferir que a peça analisada possui potencial para auxiliar crianças na aprendizagem em ciências por mobilizar a atenção e a concentração, por favorecer a retenção de informação e por estimular curiosidade e interesse. $\mathrm{O}$ fato de resultado semelhante ter sido encontrado na investigação de Peleg e Baram-Tsabari (2017) nos leva a sugerir que haja limitações do teatro de temática científica no que se refere especificamente a aprendizagem de conceitos científicos pelo público infantil. A nova hipótese a que chegamos é a de que essa limitação pode decorrer tanto da complexidade dos conceitos científicos apresentados quanto do processo de seleção e recriação que a criança realiza 
frente ao que lhe é apresentado. Por exemplo, para ela podem ser mais interessantes a roupa e o jeito de falar de um personagem do que o conteúdo do que ele diz. Assim, em pesquisas futuras é importante considerar questionamentos tais como: Qual(is) tipo(s) de aprendizagem(ns) pode(m) ser favorecida(s) por essa atividade? Qual a influência das culturas infantis nesse processo?

Acreditamos ser uma ingenuidade a expectativa de que o teatro de temática científica, atividade circunscrita em um tempo e um espaço diferenciado, poderia resultar em uma aprendizagem conceitual semelhante à ocorrida em sala de aula. Por mais que em um espetáculo teatral uma informação sobre ciências (ou um conhecimento científico) seja repetida, o tipo de reincidência não pode ser comparado com a sistemática a que a criança é submetida em sala de aula. E a tentativa de um ajuste severo de um espetáculo a parâmetros pedagógicos ou didáticos poderia levá-lo à total falência na função de comunicação com o público e em sua acepção enquanto arte preocupação de Zanetti (2018). Basta lembrar de algumas aulas tradicionais, verdadeiras materializações de "monólogos monótonos" em que as pessoas se tornam refratárias a qualquer informação, conhecimento e interação. O lugar do teatro de temática científica parece ser o de auxiliar, de maneira complementar e/ou concomitante ao que o professor desenvolve em sala de aula. Em decorrência disso, por exemplo, um professor poderia utilizar um espetáculo como mediação para posterior aprofundamento em informações sobre ciências e conceitos científicos.

Como verificamos nesta pesquisa, pelo relato de duas professoras, a curiosidade e o interesse decorrentes do espetáculo podem favorecer a motivação das crianças no aprofundamento de conhecimentos em aulas de ciências subsequentes. Apesar de não ser o foco dessa investigação, encontramos resultados que indicam a possibilidade de a atividade ter implicações na própria educação em artes. Isto porque algumas crianças relataram ser a primeira vez que assistiram uma peça de teatro e que explicitaram propensão à participação de atividades artísticas.

O espetáculo possibilitou às crianças referências que podem ser mobilizadas para o desenvolvimento da alfabetização científica (Cunha, 2017; Yacobian, 2018). Isto pôde ser percebido, por exemplo, na circulação da palavra fóton, nome de um dos personagens, que inicialmente causava estranhamento, mas depois foi naturalizada pelas crianças. Outros termos foram mencionados no grupo focal, conquanto não tenha havido a definição formal deles. Além disso, as crianças reproduziram trechos das explicações sobre respiração, sobre o funcionamento do Círculo de Newton, sobre a formação do arco-íris e sobre a dependência da luz para o aparecimento da imagem em uma foto. Nesse sentido, o espetáculo possibilitou familiarização com a ciência e se materializou como caminho para o letramento científico cultural.

Algumas limitações desta investigação referem-se à interação adulto-criança, com implicações tanto para a construção do espetáculo quanto para a coleta de dados. No primeiro caso, apesar do movimento em se compreender as culturas infantis, o olhar do adulto é restrito por não compartilhar as mesmas referências das culturas infantis. 
Isso implica em espetáculos com limitações quanto ao que significa para as crianças. Um caminho mais promissor para as montagens futuras visando a educação não formal e a divulgação científica parece ser - para além de construir personagens a partir da observação e da convivência com crianças - considerar a participação de crianças no processo criativo de montagem do espetáculo, durante os jogos teatrais, improvisações etc., abrindo espaços para a interculturalidade (Candau, 2012) entre o adulto e a criança. No segundo caso, apesar de a aproximação do pesquisador com as crianças ter considerado diversos aspectos dos debates trazidos por Ferreira (2005), Sarmento (2005) e Corsaro (2011), consideramos que uma abordagem de aporte etnográfico poderia trazer à tona maior diversidade de elementos do complexo processo de interação de uma criança com um espetáculo teatral produzido por adultos. Por exemplo, a atividade de produção de desenho poderia explicitar mais nuances (Delgado, \& Müller, 2005; Gobbi, 2005). Entretanto, as análises aqui desenvolvidas sobre os desenhos não desconsideraram as características das culturas infantis (Sarmento, 2005; Corsaro, 2009), em especial no momento do grupo focal, em que as crianças tiveram maior liberdade para se expressar.

A respeito da aproximação que realizamos entre a intencionalidade de inferir sobre o impacto de uma peça de teatro de temática científica e as culturas infantis, emerge a necessidade de em estudos futuros reorientar o questionamento de "O que as crianças percebem de uma peça de teatro de temática científica?" para "Quais as interações e interpretações de crianças espectadoras a respeito de um espetáculo de teatro de temática científica?”. Isso permitirá uma melhor explicitação das influências das culturas infantis no processo de interação e de interpretação do espetáculo, das informações científicas nele veiculadas e do impacto do espetáculo.

\section{Agradecimentos}

Agradecemos ao CNPq, ao PIBIC-UFRJ e ao PROFAX-UFRJ pela disponibilização dos recursos necessários à realização desta pesquisa, às escolas públicas do município de Macaé por nos receber em seus espaços e dividirem seus saberes, aos integrantes do Projeto Ciênica, ao Programa de Pós-Graduação em Educação em Ciências e Saúde do Instituto NUTES-UFRJ e ao Programa de Pós-Graduação em Ensino de Química do Instituto de Química-UFRJ.

\section{Referências}

Acevedo Díaz, J. A., Vásquez Alonso, A., \& Manassero Mas, M. A. (2003). Papel de la educación CTS en una alfabetización científica y tecnológica para todas las personas. Revista Electrónica de Enseñanza de las Ciencias, 2(2), 80-111. http://reec.uvigo.es/ volumenes/volumen2/REEC_2_2_1.pdf

Andrade, S. de A., Oliveira, R. D. V. L. de, Mello, W. Z. de, \& Queiroz, G. R. P. C. (2014). A abordagem CTS - arte nos estudos das estações de tratamento de esgoto: Uma prática no ensino fundamental. Revista Práxis, 6(11), 67-80. https://doi.org/10.25119/ praxis-6-11-615 
Antônio, D. G., \& Guimarães, S. T. L. (2005). Representações do meio ambiente através do desenho infantil: Refletindo sobre os procedimentos interpretativos. Educação ambiental em Ação, 14. http:www.revistaea.org/artigo.php?idartigo=343\&class $=02$

Barbacci, S. (2002). From the golem to artificial intelligence: Science in the theatre for an existential reflection. Journal of Science Communication, 1(3), 1-26. https://doi. org/10.22323/2.01030204

Bardin, L. (2000). Análise de conteúdo. Edições 70.

Bogdan, R. C., \& Biklen, S. K. (1994). Investigação qualitativa em educação. Porto Editora.

Baum, L., \& Hughes, C. (2001). Ten years of evaluating science theater at the Museum of Science, Boston. Curator: the museum journal, 44(4), 355-369. https://doi. org/10.1111/j.2151-6952.2001.tb01175.x

Bião, A. J. C. (2009). Etnocenologia e a cena baiana: textos reunidos. P\&A Gráfica e Editora.

Candau, V. M. F. (2012). Diferenças culturais, interculturalidade e educação em direitos humanos. Educação e sociedade, 33(118), 235-250. https://doi.org/10.1590/S010173302012000100015

Chemi, T., \& Kastberg, P. (2015). Education through theatre: Typologies of Science Theatre, Applied Theatre Research, 3(1), 53-65. https://doi.org/10.1386/atr.3.1.53_1

Corsaro, W. A. (2002). A reprodução interpretativa no brincar ao "faz de conta" das crianças. Educação Sociedade \& Culturas, 17, 113-134. https://www.fpce.up.pt/ciie/ revistaesc/ESC17/17-5.pdf

Corsaro, W. A. (2011). Sociologia da infância. Artmed.

Cunha, R. B. (2017). Alfabetização científica ou letramento científico?: Interesses envolvidos nas interpretações da noção de scientific literacy. Revista Brasileira de Educação, 22(68), 169-186. http://dx.doi.org/10.1590/s1413-24782017226809.

Delgado, A. C. C., \& Müller, F. (2005). Em busca de metodologias investigativas com as crianças e suas culturas. Cadernos de Pesquisa, 35(125), 161-179. https://doi.org/10.1590/ S0100-15742005000200009

Ferreira, T. (2005). Teatro infantil, crianças espectadoras, escola: Um estudo acerca de experiências e mediações em processos de recepção. (Dissertação de Mestrado em Educação). Universidade Federal do Rio Grande do Sul, Porto Alegre.

Gardair, T. L. C., \& Schall, V. T. (2009). Ciências possíveis em Machado de Assis: Teatro e ciência na educação científica. Ciência e Educação, 15(3), 695-712. https://doi. org/10.1590/S1516-73132009000300015 
Gobbi, M. (2005). Desenho infantil e oralidade: Instrumentos para pesquisas com crianças pequenas. In Faria, A. L. G., Demartini, Z. B. F., \& Prado, P. D. (eds.), Por uma cultura da infância: Metodologias de pesquisa com crianças (pp. 67-92). Autores Associados.

Gomes, A. (2005). Apontamentos sobre a pesquisa em educação: Usos e possibilidades do grupo focal. Eccos Revista Científica, 7(2), 275-290. https://doi.org/10.5585/eccos. v7i2.417

Kerby, H. W., \& Cantor, J., Weiland, M., Babiarz, C., \& Kerby, A. W. (2010). Fusion Science Theater Presents The Amazing Chemical Circus: A New Model of Outreach That Uses Theater To Engage Children in Learning. Journal of Chemical Education, 87(10), 1024-1030. https://doi.org/10.1021/ed100143j

Lopes, T. Luz, arte, ciência... ação! (2005). História, Ciências, Saúde - Manguinhos, 12, 401-418. https://doi.org/10.1590/S0104-59702005000400021

Marandino, M. (2004). Transposição ou recontextualização? Sobre a produção de saberes na educação em museus de ciências. Revista Brasileira de Educação, 26(26), 95-108. https://doi.org/10.1590/S1413-24782004000200008

Marques, A. C. T. L., \& Marandino, M. (2017). Alfabetização científica, criança e espaços de educação não formal: Diálogos possíveis. Educação e Pesquisa, 44, 1-19. http://dx.doi. org/10.1590/s1678-4634201712170831

Massarani, L., \& Almeida, C. (2006). Arte e Ciência no palco. História, Ciência e SaúdeManguinhos, 13, 233-246. https://doi.org/10.1590/S0104-59702006000500014

Moreira, L., \& Marandino, M. (2015). Teatro de temática científica: Conceituação, conflitos, papel pedagógico e contexto brasileiro. Ciência e educação, 21(2), 511-523. http://dx.doi.org/10.1590/1516-731320150020015

Moreira, L. M., \& Marandino, M. (2013). O teatro em museus e centros de ciências no Brasil, História, Ciências, Saúde - Manguinhos, 20(2), 653-673. https://doi.org/10.1590/ S0104-59702015000500011

Musacchio, G., Lanza, T., \& D’Addezio, G. (2015). An experience of science theatre to introduce earth interior and natural hazards to children. Journal of Education and Learning, 4(4), 80-90. http://dx.doi.org/10.5539/jel.v4n4p80

Neves, R., \& Massarani, L. (2008). A divulgação científica para o público infanto-juvenil: um balanço do evento. In Massarani, L. Ciência e criança: a divulgação científica para o público infanto-juvenil (pp.107-111). Museu da Vida.

Oliveira, R. D. V. L., \& Queiroz, G. R. P. C. (2013). CTS - Arte: Uma possibilidade de utilização da arte em aulas de Ciências. Conhecimento \& Diversidade, 5(9), 90-98. http:// dx.doi.org/10.18316/1241 
Peleg, R., \& Baram-Tsabari, A. (2017). Learning robotics in a science museum theatre play: Investigation of learning outcomes, contexts and experiences. Journal of Science Education and Technology, 26(6), 561-581.http://dx.doi.org/10.1007/s10956-017-9698-9 Pupo, M. L. B. (1991). No Reino da Desigualdade - Teatro infantil em São Paulo nos anos setenta. Perspectiva.

Quinteiro, J. (2002). Sobre a emergência de uma sociologia da infância: contribuições para o debate. Perspectiva, 20, 137-162. https://doi.org/10.5007/\%25x

Reigada, C., \& Tozoni Reis, M. F. C. (2004). Educação ambiental para crianças no ambiente urbano: Uma proposta de pesquisa-ação. Ciência \& Educação, 10(2),149-159. http://dx.doi.org/10.1590/S1516-73132004000200001

Saraiva, C. C. (2000). Teatro científico e ensino da química. (Dissertação de Mestrado em Química para o Ensino). Universidade do Porto, Porto.

Sarmento, M. J. (2005). Crianças: Educação, culturas e cidadania ativa. Perspectiva, 23(1), 17-40. https://doi.org/10.5007/\%25x

Sarmento, M. J., \& Pinto, M. (1997) As crianças e a infância: Definindo conceitos, delimitando o campo. In Pinto, M., \& Sarmento, M. J. (Orgs.) As crianças: Contextos e identidades (pp. 9-30). Centro de estudos da criança.

Silveira, A. F., Ataíde, A. F. P., \& Freire, M. L. F. (2009). Atividades lúdicas no ensino de ciências: Uma adaptação metodológica através do teatro para comunicar a ciência a todos. Educar, 34, 251-262. https://doi.org/10.1590/S0104-40602009000200016

Silveira, E. (2009). A arte do encontro: A educação estética ambiental atuando com o Teatro do Oprimido. Educação em Revista, 25(3), 369-394. https://doi.org/10.1590/ S0102-46982009000300018

Sirota, R. (2001). Emergência de uma Sociologia da Infância: Evolução do objeto e do olhar. Cadernos de Pesquisa, 112, 7-31. https://doi.org/10.1590/S0100-15742001000100001

Viana, I. (2019). História do teatro para crianças no eixo Rio-São Paulo. Centro Brasileiro de Teatro para a infância e a Juventude. https://cbtij.org.br/historia-teatro-para-criancaseixo-rio-sao-paulo/

Voegel, P., Quashnock, K. \& Heil, K. (2004). The student-to-student chemistry initiative: Training high school students to perform chemistry demonstration programs for elementary school students. Journal of Chemical Education, 81(5), 681-684. https://doi. org/10.1021/ed081p681

Zanetti, F. L. (2018). O encontro da arte com a educação: o papel do saber psicológico. Educação em Revista, 34, 255-276. https://doi.org/10.1590/0102-4698168370

Yacoubian, H. A. (2018). Scientific literacy for democratic decision-making. International Journal of Science Education, 40(3), 308-327. https://doi.org/10.1080/09500693.2017.1 420266 


\section{Leonardo Maciel Moreira}

${ }^{0}$ https://orcid.org/0000-0002-0543-9085

Universidade Federal do Rio de Janeiro Licenciatura em Química Macaé, Rio de Janeiro, Brasil leo.qt@hotmail.com

Viktória Aparecida Gomes Silva Coelho

https://orcid.org/0000-0003-3514-5309 Universidade Federal do Rio de Janeiro Licenciatura em Ciências Biológicas

Macaé, Rio de Janeiro, Brasil viktoriacoelho@gmail.com

Laise Novellino Nunes de Souza

${ }^{\circ}$ https://orcid.org/0000-0002-9109-2101 Instituto Federal Fluminense Programa de Pós-graduação em Engenharia Ambiental Macaé, Rio de Janeiro, Brasil lalanovellino@hotmail.com

Submetido em 27 de março de 2020 Aceito em 18 de junho de 2020 Publicado em 10 de julho de 2020 